\title{
Effect of Photoperiod and Temperature on the Diapause Termination of the Kanzawa Spider Mite, Tetranychus kanzawai Kishida (Acari: Tetranychidae)
}

\author{
Masatoshi MOCHIZUKI ${ }^{1}$ and Akio TAKAFUJI ${ }^{2}$ \\ 1 Pest Control Laboratory, Department of Tea Agronomy, National Research Institute \\ of Vegetables Ornamental Plants and Tea, Kanaya, Shizuoka 428, Japan \\ ${ }^{2}$ Laboratory of Ecological Information, Graduate School of Agriculture, \\ Kyoto University, Kyoto 606-01, Japan.
}

(Received 14 June 1996; Accepted 4 September 1996)

\begin{abstract}
Mochizuki, M. and A. Takafuji, 1996. Effect of photoperiod and temperature on the diapause termination of the Kanzawa spider mite, Tetranychus kanzawai Kishida (Acari: Tetranychidae). J. Acarol. Soc. Jpn., 5(2): 83-88.
\end{abstract}

Reproductive diapause of the adult females of the Kyoto population of Tetranychus kanzawai induced under laboratory conditions ended much faster under long-day (16 L 8D) than under short-day $(9 \mathrm{~L} 15 \mathrm{D})$. Temperature also played a part; the diapause ended quicker at $20^{\circ} \mathrm{C}$ than at $15^{\circ} \mathrm{C}$. The majority of females did not require any chilling for diapause termination. These results suggested that the diapause intensity of T. kanzawai in central Japan was weak and short-days maintained diapause. Overwintering adult females collected from a tea field in Shizuoka gradually lost sensitivity to short-days after December. More than half of the females collected in late December started oviposition within about 10 days when exposed to both short-days and to long-days. This result indicated that the diapause of T. kanzawai had ended by mid-winter.

Key words: Tetranychus kanzawai, diapause termination, diapause intensity

\section{INTRODUCTION}

The Kanzawa spider mite, Tetranychus kanzawai Kishida is one of the major pests of tea, fruit trees, vegetables and ornamental plants in Japan. This mite shows a reproductive diapause induced by short-days and low temperatures in autumn, and overwinters as adult females (Osakabe, 1967). Females in diapause are easy to recognize by the change in body color from dark red to bright cinnabar. Reactivated females begin oviposition in early spring, and the density of the mites increases thereafter. Acaricidal control against these reactivated females is effective for preventing a subsequent, rapid population increase in late spring. It is important, therefore, to estimate the time of diapause termination in the field.

A number of studies have been reported on the diapause termination of the twospotted spider mite, T. urticae (see a review by Veerman, 1985). Chilling periods are 
needed for some populations to end diapause, while others end diapause without them. The required chilling period duration for diapause termination is known to vary among geographical populations (Lees, 1953; Parr and Hussey, 1966; Gotoh, 1986). Photoperiod also greatly affects diapause termination as well. Long-days enhance the termination, whereas short-days maintain diapause status (Veerman, 1977; Koveos et al., 1993).

With the diapause termination of T. kanzawai, only a limited number of studies have been published. Osakabe (1967) showed long-days and high temperatures quickly terminated diapause of females collected from a tea field of Shizuoka (central Honsyu) in mid-December. Uchida (1980) supposed that most overwintering females in a pear orchard in Tottori had terminated diapause by early December, because nearly $90 \%$ of the females collected in late December had started oviposition within 20 days under 14 $\mathrm{L} 10 \mathrm{D}$ at $15^{\circ} \mathrm{C}$. The accelerated diapause termination under long-days observed in $T$. urticae implies that it is also the case with $T$. kanzawai: diapause state may be maintained later in the field than previously estimated based on laboratory treatment of long-days. Thus, precise studies are obviously needed on the effects of photoperiod as well as temperature on the diapause termination of T. kanzawai. The present study elucidates these effects by using both laboratory- and field-induced diapausing females of T. kanzawai, and clarifies the time when the mites end diapause in the field.

\section{MATERIALS AND METHODS}

Effects of photoperiod and temperature on diapause termination. The population used here was collected from a tea field in Kyoto city in April 1985 and was maintained on bean leafdiscs (Phaseolus vulgaris L.) under laboratory conditions of $16 \mathrm{~L} 8 \mathrm{D}$ at $20-25^{\circ} \mathrm{C}$.

For diapause induction, 20-30 adult females were allowed to oviposit on each leafdisc for $24-48 \mathrm{hr}$ under $16 \mathrm{~L} 8 \mathrm{D}$ at $15^{\circ} \mathrm{C}$ or $20^{\circ} \mathrm{C}$. Eggs were then reared to the adults under $9 \mathrm{~L} 15 \mathrm{D}$ at either of the temperatures. Adult females thus reared were maintained under the same photoperiod regime as in the immature stages either for two weeks at $20^{\circ} \mathrm{C}$ or three weeks at $15^{\circ} \mathrm{C}$ after adult emergence. Under these conditions, $100 \%$ of adult females entered diapause.

In order to elucidate the effect of photoperiod on diapause termination, diapausing females obtained under $9 \mathrm{~L} 15 \mathrm{D}$ at $20^{\circ} \mathrm{C}$ were individually transferred onto leafdiscs $(1$ $\times 1 \mathrm{~cm}$ ) and maintained under each of four photoperiod regimen, $9 \mathrm{~L} 15 \mathrm{D}, 11 \mathrm{~L} 13 \mathrm{D}, 13 \mathrm{~L}$ $11 \mathrm{D}$ and $16 \mathrm{~L} 8 \mathrm{D}$, at $20^{\circ} \mathrm{C}$. The mites were observed at $2-7$ day intervals for 65 days. Once oviopsition had started, they were determined to have terminated diapause.

Effect of temperature on diapause termination was studied by using diapausing females induced under $9 \mathrm{~L} 15 \mathrm{D}$ at $15^{\circ} \mathrm{C}$. The females were individually transferred onto leafdiscs $(1 \times 1 \mathrm{~cm})$ and maintained under $15^{\circ} \mathrm{C}$ or $20^{\circ} \mathrm{C}$ with $9 \mathrm{~L} 15 \mathrm{D}$. Observation lasted 48 days. Combined effects of long-days and temperature on diapause termination were also studied. Diapausing females induced under $9 \mathrm{~L} 15 \mathrm{D}$ at $15^{\circ} \mathrm{C}$ were transferred to 16 $\mathrm{L} 8 \mathrm{D}$ at $20^{\circ} \mathrm{C}$, in the same manner as mentioned above, and observation lasted 14 days.

Diapause termination in the field. As was shown in T. urticae (Veerman, 1977), 
sensitivity of diapausing T. kanzawai to short-days which maintain its diapause state may be gradually lost. We studied the changes in this sensitivity by periodically collecting females from the field and estimated the time of diapause termination. Twenty to eighty adult females in diapause were collected at 15-30 day intervals from November 1987 to February 1988 from a tea field in Kanaya, Shizuoka Prefecture. These mites were individually transferred to leafdiscs $(1 \times 1 \mathrm{~cm})$, which were divided into two groups. One was kept under $9 \mathrm{~L} 15 \mathrm{D}$, and the other under $16 \mathrm{~L} 8 \mathrm{D}$ at $15^{\circ} \mathrm{C}$. Diapause termination was observed in the same manner as mentioned above.

\section{RESULTS AND DISCUSSION}

Females subjected under longer day lengths than $13 \mathrm{~L} 11 \mathrm{D}$ began oviposition only after 4 to 7 days at $20^{\circ} \mathrm{C}$ (Fig. $1 \mathrm{~A}$ ), whereas those under short-days $(9 \mathrm{~L} 15 \mathrm{D}$ and $11 \mathrm{~L} 13$ D) required 17 to 18 days until they started oviposition (Fig. $1 \mathrm{~A}$ ). These results revealed that duration of diapause was shortened under long-days and chilling was unnecessary for them to end diapause.

Diapause termination under short-day $(9 \mathrm{~L} 15 \mathrm{D})$ occurred earlier at $20^{\circ} \mathrm{C}$ than at $15^{\circ} \mathrm{C}$ (Fig. 1B). Females began to oviposit within 5 days and more than half of them oviposited by day 12 at $20^{\circ} \mathrm{C}$, whereas at $15^{\circ} \mathrm{C}$ it was after 35 days when half of the females began to oviposit. Start of oviposition was further hastened under long-day (16 L $8 \mathrm{D}$ ) at $20^{\circ} \mathrm{C}$ (Fig. $1 \mathrm{~B}$ ), and more than $95 \%$ of females oviposited after 10 days.

The field-induced diapausing females collected in mid-November required more than 40 days until $50 \%$ of them started oviposition under 9 L 15 D (Fig. 2 A), whereas only 15 days was necessary under 16 L 8D (Fig. 2B). However, the mites collected in midDecember from the field rapidly started oviposition after 10 days under short-day. Finally, more than half of the females collected in late December oviposited within about 10 days under both short-(Fig. 2 A) and long-day (Fig. 2 B).

Diapause intensity of $T$. urticae has been measured in terms of the duration of chilling period required for diapause termination (Lees, 1953; Parr and Hussy, 1966; Koveos et al., 1993). However, the laboratory-induced females of the Kyoto population of T. kanzawai terminated diapause without chilling even under short-days. Such an observation is also made in the Greek strain of $T$. urticae, which ended diapause without being exposed to chilling conditions (Koveos et al., 1993). Although most females of the Kyoto population of $T$. kanzawai enter diapause, the intensity of diapause is thought to be weak.

Veerman (1977) showed that photoperiodic sensitivity of diapausing females of $T$. urticae to short-day which maintained diapause was retained during the first 2.5 months of diapause, and thereafter this sensitivity apparently disappeared. This fact suggests that it is the exact time of end of diapause state when the reactivation pattern under short-days becomes identical to that under long-days. However, the pattern of diapause termination of $T$. kanzawai has been studied so far only under long-days (Osakabe, 1967; Uchida, 1980). It is now evident that the diapausing state of $T$. kanzawai is also terminated faster under long-days as well as at high temperatures, and short- 

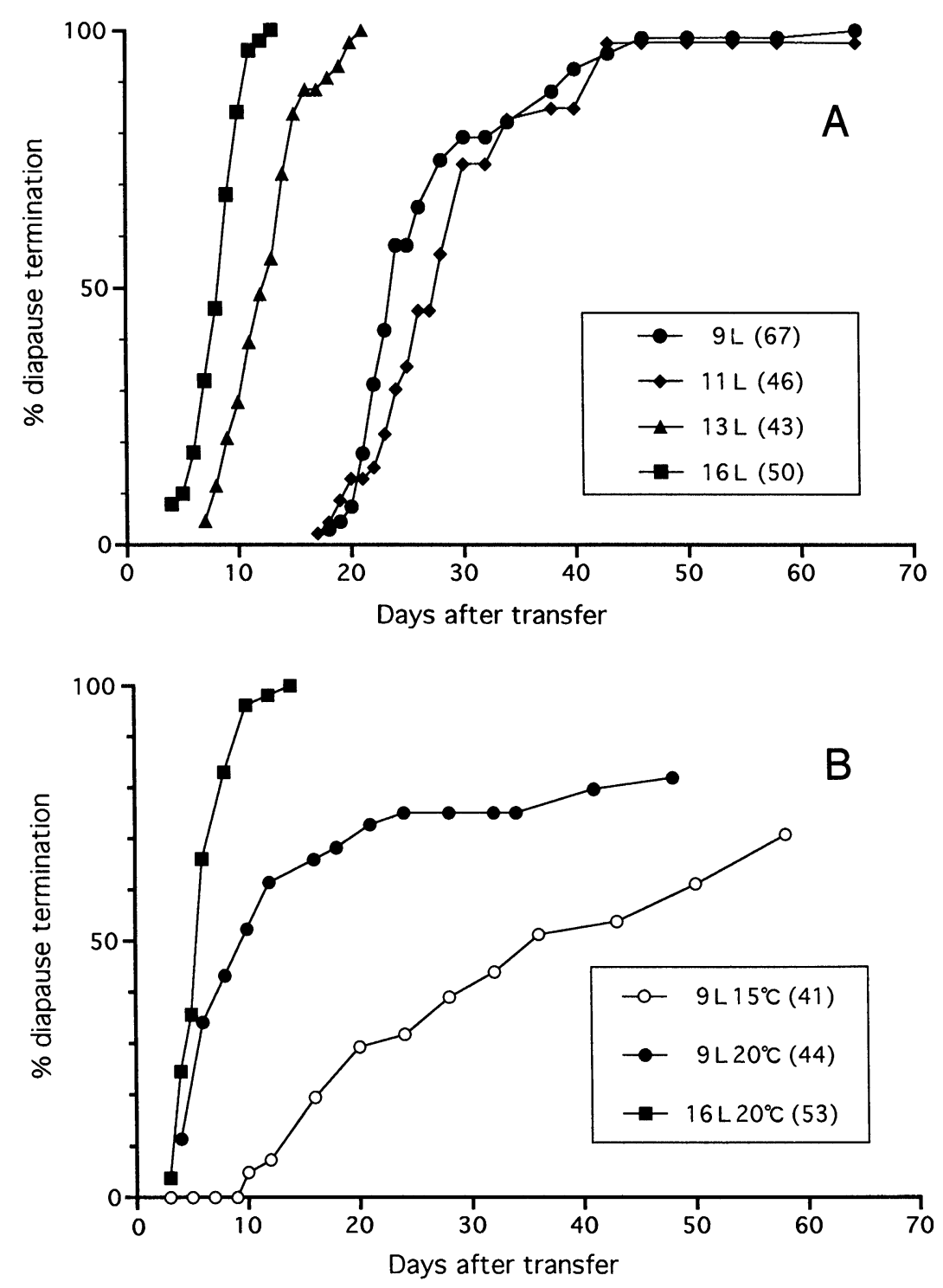

Fig. 1. Effect of photoperiod and temperature on diapause termination of the Kyoto population of $T$. kanzawai. (A) Diapause-induced females were kept for 2 weeks after adult emergence under $9 \mathrm{~L} 15 \mathrm{D}$ at $20^{\circ} \mathrm{C}$, and then transferred to various photoperiod regimen. (B) Diapause-induced females were kept for 3 weeks after adult emergence under $9 \mathrm{~L} 15 \mathrm{D}$ at $15^{\circ} \mathrm{C}$, and then transferred to $20^{\circ} \mathrm{C}$ under $9 \mathrm{~L} 15 \mathrm{D}$ or $16 \mathrm{~L} 8 \mathrm{D}$. Numerals in parentheses are the number of individuals tested.

days maintain diapause. Thus, the result of the present study reveals that the time of diapause termination determined in the former studies was estimated earlier than it actually occurs in the field.

The present study confirms that short-days maintain the diapausing state of over- 

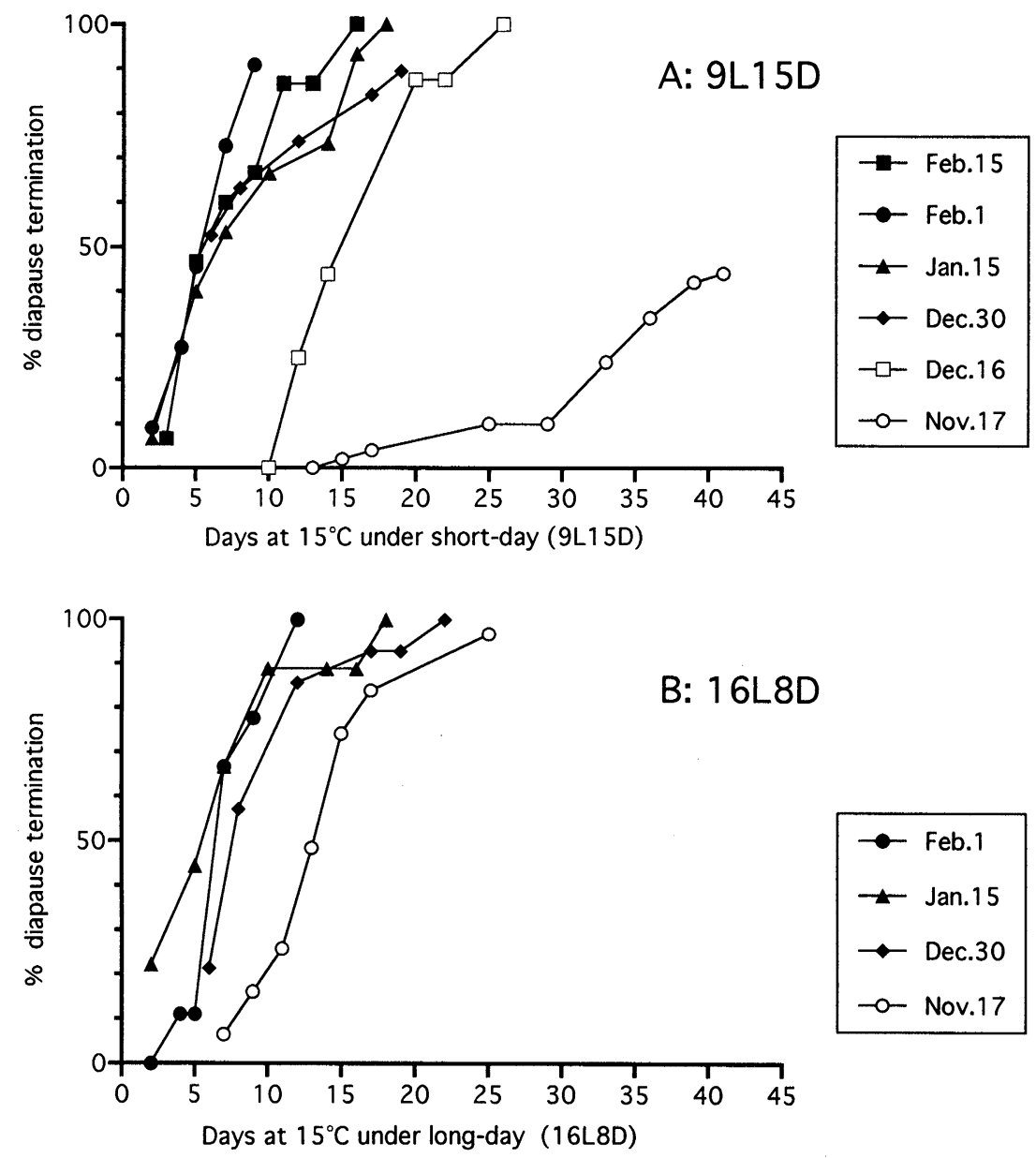

Fig. 2. Effect of photoperiod (A: $9 \mathrm{~L} 15 \mathrm{D}, \mathrm{B}: 16 \mathrm{~L} 8 \mathrm{D}$ ) at $15^{\circ} \mathrm{C}$ on diapause termination of the adult females of $T$. kanzawai collected in a tea field at Shizuoka during winter. Dates in panels indicate the time of collection of the mites from the field.

wintering T. kanzawai, but this effect of short-days is lost in late December. Therefore, diapausing state is maintained until this period. Thus, the study indicates the diapause termination in the field of central Japan begins at the year-end, which is later than estimated in previous studies under long-days. Overwintering females in this area are ready to lay eggs whenever temperature rises, even in mid-winter.

\section{摘 要}

カンザワハダニの休眠覚醒に及ぼす日長と温度の効果

望月雅俊 (野菜茶試茶栽培部) ・高藤晃雄 (京都大学農学研究科)

カンザワハダニの休眠覚醒に対する日長と温度の効果, および野外での休眠覚醒時期を調 
べた。20ㄷ短日条件（9L 15D）で休眠誘起されたカンザワハダニ（京都市産）の休眠覚醒は, 長日条件下（16 L 8D) のほうが短日条件下（9L 15 D) よりあはるかにはやく進行した。短日 条件では $15^{\circ} \mathrm{C}$ りも $20^{\circ} \mathrm{C}$ のうがよりはやく覚醒が進み， $20^{\circ} \mathrm{C}$ 長日条件ではきわめて速や かに覚醒された。覚醒のためには低温処理は全く必要なく，この個体群の休眠は浅いと考え られた。また，冬期に野外（静岡県榛原郡金谷町）から定期的に採集した休眠雌成虫に対す る短日の休眠維持効果は徐々に消失した。12 月末以降に野外で採集した雌成虫を $15^{\circ} \mathrm{C}$ 移 すと, 日長条件にかかわらず 10 日以内に $50 \%$ 以上が産卵を再開し, ほとんどの雌成虫の休 眠覚醒は 12 月末までには終了していると考えられた。

\section{REFERENCES}

Gotoh, T. (1986): Termination pattern of diapause in the two-spotted spider mite, Tetranychus urticae Koch (Acarina: Tetranycidae) in Sapporo. Appl. Ent. Zool., 21: 480-481.

Koveos, D. S., A. Kroon and A. Veerman (1993): Geographic variation of diapause intensity in the spider mite Tetranychus urticae. Physiol. Entomol., 18: 50-56.

Lees, A. D. (1953): Environmental factors controlling the evocation and termination of diapause in the fruit tree red spider mite, Metatetranychus ulmi Koch (Acarina: Tetranychidae). Ann. Appl. Biol., 40: 449-486.

Osakabe, M. (1967): Biological studies on the tea red spider mite, Tetranychus kanzawai Kishida, in tea plantation. Bull. Natl. Res. Inst. Tea., 4: 35-166. (in Japanese with English summary)

Parr, W. J. and N. W. Hussey (1966): Diapause in the glasshouse red spider mite (Tetranychus urticae Koch): A synthesis of present knowledge. Hort. Res., 6: 1-21.

Uchida, M. (1980): Appearance time of diapausing females and termination of diapause in the two spotted spider mite, Tetranychus urticae Koch and the Kanzawa spider mite, Teranychus kanzawai Kishida on pear tree in Tottori district (Acarina: Tetranychidae). Jap. J. Appl. Ent. Zool., 24: 175-183. (in Japanese with English summary)

Veerman, A. (1977): Photoperiodic termination of diapause in spider mites. Nature, 266: 526-527.

Veerman, A. (1985): Diapause. In: Spider Mites. Their Biology, Natural Enemies and Control, Vol. 1 A (eds., W. Helle and M.W. Sabelis), pp.279-316, Elsevier, Amsterdam. 